\title{
Currently Available Tools and Teaching Strategies for the Interprofessional Education of Students in Health Professions Literature review
}

Nelofar S. Khan, ${ }^{1}$ Syed I. Shahnaz, ${ }^{2}$ Kadayam G. Gomathi ${ }^{1}$

$$
\begin{gathered}
\text { الأدوات واستراتيجيات التدريس البيني للتعليم المهني المتاحو حالياً لطالب المهن الصحية } \\
\text { المراجعة الأدبيات }
\end{gathered}
$$

نيلوفر سامي خان، سيد إلياس شاهناز، كاديام جوماثي

\begin{abstract}
Interprofessional education (IPE) is designed to provide students from different health sectors with opportunities to work together to enhance future collaboration. The implementation of IPE activities is a current trend in various countries. This review exclusively targets IPE issues involving undergraduate health profession students and highlights various approaches in different regions. A total of 28 articles published in peer-reviewed journals between January 2012 and July 2015 were assessed to determine recent trends in IPE implementation. Nine main strategies were identified: simulation-based education programmes; rotations in rural and community settings; interprofessional training wards; patient-centred case studies; theme-centred workshops; student seminars; student-delivered lectures; health promotion activities; and interactive lectures in a common setting. Many of these institutions had not restricted themselves to a single strategy and supplemented these activities with additional teaching or learning methods. Recommendations gathered from these diverse approaches may assist the development of sustainable strategies for implementing IPE in undergraduate medical curricula.
\end{abstract}

Keywords: Interprofessional Relations; Interdisciplinary Communication; Undergraduate Medical Education; Health Professions.

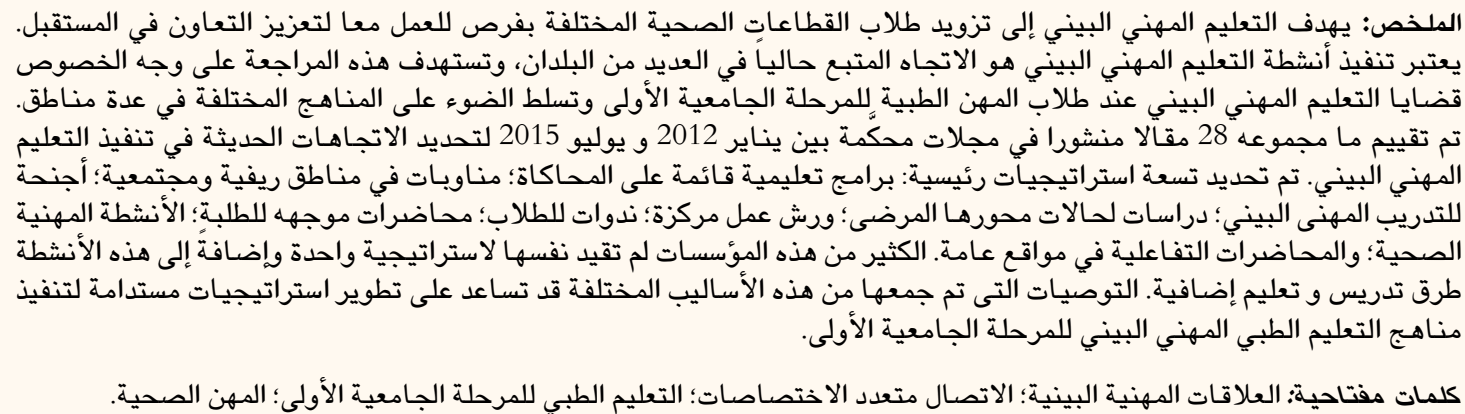

A $\mathrm{N}$ INCREASED LIFE EXPECTANCY AND incidence of chronic health conditions requiring prolonged follow-up and multiple therapies or treatment approaches characterise the present day patient population. Numerous options for treatment and management, evolving healthcare policies and healthcare organisational structures demanding superior results with limited resources represent existing challenges for healthcare delivery. ${ }^{1,2}$ Hierarchical teams with insufficient experience of interdisciplinary collaboration and a lack of effective communication among healthcare professionals have been reported as possible reasons for the poor quality of care sometimes provided to patients. ${ }^{3}$ Hence, it is expected that a more cooperative team approach in the form of interprofessional collaborative practices may overcome these challenges to provide a higher quality of patient care. ${ }^{1,2}$

In most parts of the world, healthcare professionals are trained predominantly in intraprofessional settings, in which educational activities occur only among students within the same profession without inter- 
action with students from other fields; each profession thus organises its own teaching and is unaware of what is taught or learnt in other professions. ${ }^{1,4}$ Generally, students graduating from traditional training programmes do not possess interprofessional expertise, have unclear role definitions and lack the crucial communication skills needed to collaborate competently with other members of a healthcare team. ${ }^{3,5}$ Unfortunately, this can result in problems in healthcare delivery, the inefficient utilisation of available resources, suboptimal patient care and workplace conflicts. ${ }^{6}$

Interprofessional education (IPE) provided during training can overcome these problems by producing a practice-ready workforce. ${ }^{7}$ Briefly, IPE trains graduates to be efficient and successful team members with the requisite skills and attitudes needed for problemsolving and good communication and collaboration between various healthcare professionals. ${ }^{8}$ In IPE, each profession looks at a topic, problem or case from its own perspective as well as that of other professions. ${ }^{1,4}$ It involves students from two or more related disciplines learning about, from and with each other during their professional training. The aim of IPE is to develop effective collaboration and team behaviours in order to achieve improved health outcomes for patients. ${ }^{9}$ Thus, IPE educators and students jointly create a collaborative learning atmosphere both in academic- and work-based settings and before and after qualification. ${ }^{10}$ As the responsibility for teaching teamwork and collaboration falls primarily to educators, IPE must be an intentional collaborative effort with the willing participation of faculty members and students from multiple disciplines. ${ }^{11,12}$

In 2006, the World Health Organization (WHO) created the IPE Study Group with the aim of developing a universal plan for ensuring the execution of IPE and collaborative practices globally. ${ }^{13}$ The WHO subsequently issued the Framework for Action on Interprofessional Education and Collaborative Practice in 2010. ${ }^{2}$ A report from the Interprofessional Education Collaborative in 2011 concluded that, in a continuously evolving healthcare system, future healthcare professionals should be educated and trained in a collaborative manner. ${ }^{5}$ Subsequently, accrediting bodies involved in health professional education and training recognised the need for IPE and initiated the process of developing accreditation standards for incorporating IPE in all healthcare-related education programmes such as medicine, nursing, pharmacy, physiotherapy, occupational therapy and social work. ${ }^{5}$ Organisations such as the Accreditation of Interprofessional Health Education, the Accreditation Council for Graduate Medical Educ- ation, the Institute of Medicine, the Accreditation Council for Pharmacy Education, the Center for the Advancement of Pharmacy Education, the American Dental Education Association, the American Association of Colleges of Nursing and the National League for Nursing issued joint guidelines outlining the necessary competencies required for graduates of accredited programmes to function as members of an interprofessional team. ${ }^{5}$

With increased recognition of the value of IPE for interprofessional collaborative practice, the development and implementation of effective IPE practices have become a priority. ${ }^{12}$ In the USA, the aforementioned competencies have been outlined to assist with the delivery of IPE within medical education curricula. ${ }^{5}$ In Australia, government and independent reports were released which emphasised the inclusion of IPE in health profession training programmes. ${ }^{14}$ Furthermore, the governments of Canada and the USA have awarded funding to universities to introduce IPE training for health professional students early in their curricula. $^{15,16}$ Although IPE has attained extensive support-including reinforcement through various government and accreditation bodies-the extent of commitment to IPE principles remains variable. Although IPE is a part of medical school curricula in many countries, including Canada, the USA, the UK and Australia, there is little documentation of IPE initiatives in many developing countries, including those in the Middle East. ${ }^{1,17,18}$ The main objective of this review was to discuss the various innovative approaches adopted and models developed and/ or pilot-tested to deliver IPE in different parts of the world, exclusively targeting IPE issues involving undergraduate health profession trainees.

\section{Methods}

The MEDLINE, ProQuest, Cumulative Index to Nursing and Allied Health Literature, PsycINFO and Education Resources Information Center databases were searched for publications linked to IPE. In addition, the following journals were also searched: Medical Teacher, Journal of Interprofessional Care, Teaching and Learning in Medicine, Medical Education, Academic Medicine and Advances in Health Sciences Education. The following search terms were used in various combinations: "interprofessional education", "undergraduate students", "guidelines", "models", "implementation" and "challenges and barriers". Only publications in which the participants were undergraduate students in health professions (e.g. nursing, medicine, social work, nutrition/dietetics, pharmaceutical sciences, dentistry, occupational therapy and physiotherapy) 


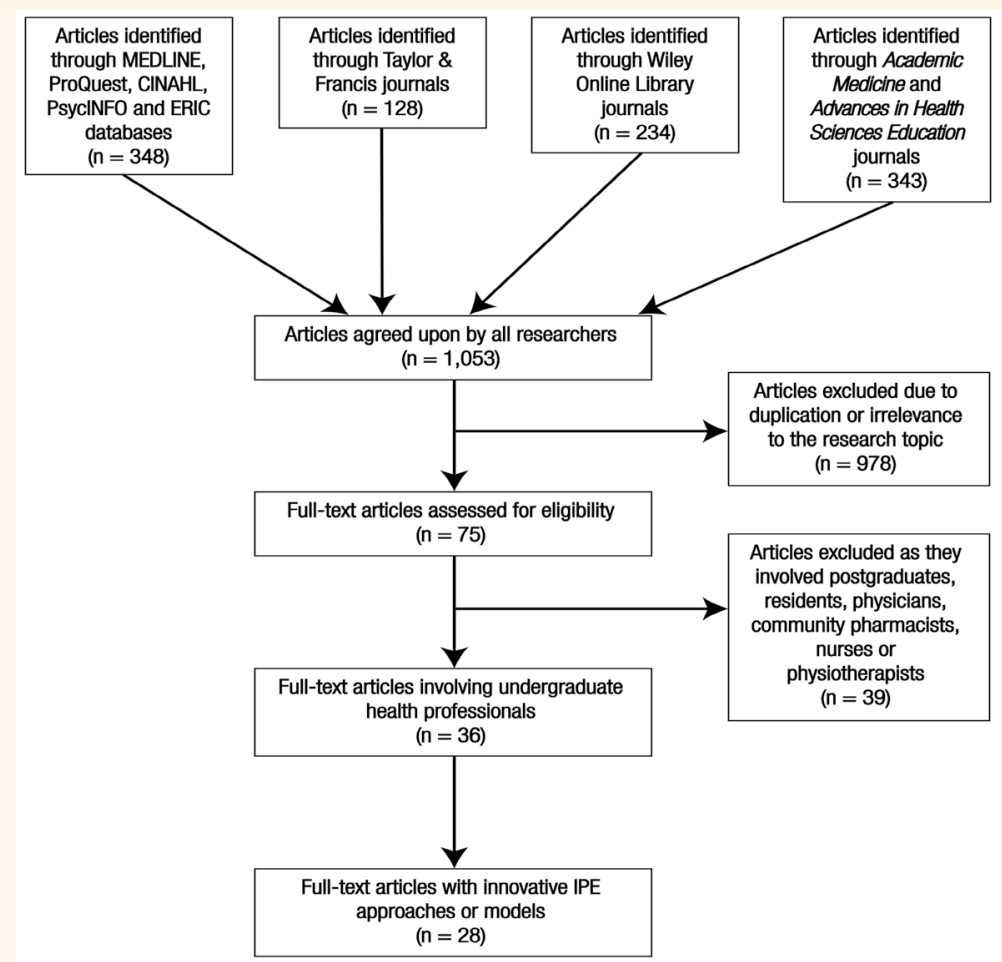

Figure 1: Flowchart of the process used to identify articles for inclusion in the literature review.

$C I N A H L=$ Cumulative Index to Nursing and Allied Health Literature; ERIC = Education Resources Information Center; IPE = interprofessional education.

were included. Articles involving postgraduates, residents, physicians, community pharmacists, nurses or physiotherapists were excluded. In addition, the inclusion criteria required that the article include an educational intervention focusing on the delivery of IPE and an assessment of the effectiveness of this intervention. Full-text original research articles, reviews and editorials were assessed for eligibility. Articles published between January 2012 and July 2015 involving qualitative, quantitative or blended research were included to fill in the gap of existing knowledge. Articles in English and English abstracts of articles published in other languages were focused upon.

The following details were extracted from each article using a data abstraction form: location, innovative approaches developed and utilised for imparting IPE and challenges and guidelines for the implementation of IPE. The abstraction form was pilot-tested and refined through an iterative process before use. Data were extracted by all three researchers and differences, if any, were resolved by consensus. A total of 1,053 articles were identified, of which 978 were excluded due to duplication or irrelevance to the topic and 39 were excluded as the participants were not undergraduate students in health professions. The literature search and article identification procedure is shown in Figure 1. Information available from the WHO, the Centre for the Advancement of
Interprofessional Education in the UK, accreditation guidelines for different health professions and government policy documents were also included.

\section{Results}

Among the 36 selected articles published between January 2012 and July 2015, 28 focused on innovative strategies for imparting IPE to undergraduate health professional students [Table 1], ${ }^{6,11,17,19-43}$ A total of 15 articles originated from the USA, indicating a high interest in IPE programmes in this country. ${ }^{11,20-22,24-26,28,32,35,36,38-40,42}$ For the rest, three studies each were conducted in the UK and Canada, two in Australia and one each in Sweden, Malaysia, the Philippines, China and Switzerland. 6,17,19,23,27,29-31,33,34,37,41,43 Nine main strategies were identified for executing IPE activities: simulation-based education programmes; rotations in rural and community settings; interprofessional training wards; patient-centred case studies; theme-centred workshops; student seminars; student-delivered lectures; health promotion activities; and interactive lectures in a common setting., ${ }^{6,11,17,19-43}$ Many of the institutions implementing IPE had not restricted themselves to one strategy and instead supplemented the aforementioned activities with additional teaching/ learning methods..$^{6,24,26,42}$ 
Table 1: Summary of a literature review of recent interprofessional education strategies for undergraduate health professional students

\begin{tabular}{|c|c|c|c|c|}
\hline $\begin{array}{l}\text { Author and year } \\
\text { of article }\end{array}$ & Location & Professions represented & Main strategy & Description \\
\hline Gum et al. ${ }^{6} 2013$ & Australia & $\begin{array}{l}\text { Nutrition and dietetics, } \\
\text { speech pathology, } \\
\text { paramedics }\end{array}$ & $\begin{array}{l}\text { Rotations in rural } \\
\text { settings }\end{array}$ & $\begin{array}{l}\text { A programme designed to promote } \\
\text { interprofessional learning in rural settings } \\
\text { (IMMERSe) }\end{array}$ \\
\hline Vyas et al. ${ }^{11} 2012$ & USA & $\begin{array}{l}\text { Medicine, pharmacy, } \\
\text { nursing and others }\end{array}$ & $\begin{array}{l}\text { Simulation- } \\
\text { based education } \\
\text { programme }\end{array}$ & $\begin{array}{l}\text { Patient simulation was used for semi-urgent } \\
\text { case scenarios }\end{array}$ \\
\hline Opina-Tan ${ }^{17} 2013$ & Philippines & $\begin{array}{l}\text { Allied medical professions, } \\
\text { medicine, nursing and } \\
\text { nutrition }\end{array}$ & $\begin{array}{l}\text { Rotation in a } \\
\text { community setting }\end{array}$ & $\begin{array}{l}\text { FCM involving interprofessional teams } \\
\text { during community rotation }\end{array}$ \\
\hline Wang et al..$^{19} 2015$ & China & Nursing and medicine & $\begin{array}{l}\text { Simulation- } \\
\text { based education } \\
\text { programme }\end{array}$ & $\begin{array}{c}\text { Interprofessional simulation-based } \\
\text { educational programme about operating } \\
\text { room nursing }\end{array}$ \\
\hline $\begin{array}{l}\text { Cappiello et al. }{ }^{20} \\
2015\end{array}$ & USA & $\begin{array}{l}\text { Nursing, physician } \\
\text { assistants and medicine }\end{array}$ & $\begin{array}{l}\text { Rotation in a } \\
\text { community setting }\end{array}$ & $\begin{array}{c}\text { Experience in a community health centre to } \\
\text { introduce students to IPC in underserved } \\
\text { areas }\end{array}$ \\
\hline $\begin{array}{l}\text { McBride et } a l .^{21} \\
2015\end{array}$ & USA & $\begin{array}{l}\text { Physician assistants and } \\
\text { medicine }\end{array}$ & $\begin{array}{l}\text { Student-delivered } \\
\text { lectures }\end{array}$ & $\begin{array}{c}\text { Clinical anatomy course where physician } \\
\text { assistant students were taught by medical } \\
\text { students }\end{array}$ \\
\hline $\begin{array}{l}\text { Diwan et al. } \\
2016^{*}\end{array}$ & USA & $\begin{array}{l}\text { Students across multiple } \\
\text { programmes }\end{array}$ & $\begin{array}{l}\text { Health promotion } \\
\text { activities }\end{array}$ & $\begin{array}{c}\text { Community health promotion providing } \\
\text { information to older adults in an IPC } \\
\text { setting (SWFs) }\end{array}$ \\
\hline $\begin{array}{l}\text { Herrmann et al. } \\
2015\end{array}$ & Switzerland & Medicine and nursing & $\begin{array}{l}\text { Interactive lectures } \\
\text { in a common } \\
\text { setting }\end{array}$ & $\begin{array}{l}\text { Pilot project in which nursing topics and } \\
\text { anatomy lectures were combined }\end{array}$ \\
\hline $\begin{array}{l}\text { Arndell et al. }{ }^{24} \\
2014\end{array}$ & USA & Pharmacy and medicine & $\begin{array}{l}\text { Rotation in a } \\
\text { community setting }\end{array}$ & $\begin{array}{l}\text { Student teams and community partners } \\
\text { provided healthcare in local homeless } \\
\text { shelter facilities, conducted health } \\
\text { education sessions and participated in } \\
\text { street outreach }\end{array}$ \\
\hline $\begin{array}{l}\text { Bolesta et al. }{ }^{25} \\
2014\end{array}$ & USA & Pharmacy and nursing & $\begin{array}{l}\text { Simulation- } \\
\text { based education } \\
\text { programme }\end{array}$ & $\begin{array}{l}\text { Patient-care scenarios using a high-fidelity } \\
\text { patient simulator }\end{array}$ \\
\hline $\begin{array}{l}\text { Shrader et al. }{ }^{26} \\
2014\end{array}$ & USA & $\begin{array}{l}\text { Medicine, nursing and } \\
\text { physician assistants }\end{array}$ & $\begin{array}{l}\text { Simulation- } \\
\text { based education } \\
\text { programme and } \\
\text { theme-centred } \\
\text { workshops }\end{array}$ & $\begin{array}{c}\text { Nine separate IPE activities embedded into } \\
\text { a required clinical assessment course over } \\
\text { a semester using various active-learning } \\
\text { strategies }\end{array}$ \\
\hline $\begin{array}{l}\text { Morphet et al. }{ }^{27} \\
2014\end{array}$ & Australia & $\begin{array}{l}\text { Nursing, medicine, } \\
\text { social work, nutrition/ } \\
\text { dietetics, pharmacy and } \\
\text { occupational therapy }\end{array}$ & $\begin{array}{l}\text { Interprofessional } \\
\text { training ward }\end{array}$ & $\begin{array}{c}\text { Real-life clinical training in IPE training } \\
\text { wards in hospitals under professional } \\
\text { supervision }\end{array}$ \\
\hline $\begin{array}{l}\text { von der Lancken } \\
\text { et al. } .^{28} 2014\end{array}$ & USA & $\begin{array}{l}\text { Nursing and physical } \\
\text { therapy }\end{array}$ & $\begin{array}{l}\text { Simulation- } \\
\text { based education } \\
\text { programme and } \\
\text { theme-centred } \\
\text { workshops }\end{array}$ & $\begin{array}{l}\text { Physical therapy students taught safe } \\
\text { patient-handling skills in a simulated setting } \\
\text { to undergraduate nursing students }\end{array}$ \\
\hline Tan et al..$^{29} 2014$ & Malaysia & Medicine and pharmacy & $\begin{array}{l}\text { Rotations in a } \\
\text { community setting }\end{array}$ & $\begin{array}{l}\text { Visits to patients' homes and to related } \\
\text { community-based organisations (CHC) }\end{array}$ \\
\hline $\begin{array}{l}\text { Netherwood } \\
\text { et al. } .^{30} 2014\end{array}$ & UK & $\begin{array}{l}\text { Nursing, midwifery, } \\
\text { homeopathy and } \\
\text { complementary therapies }\end{array}$ & $\begin{array}{l}\text { Theme-centred } \\
\text { workshops }\end{array}$ & IPE workshops and focus-group discussions \\
\hline $\begin{array}{l}\text { Hardisty et al. }{ }^{31} \\
2014\end{array}$ & UK & $\begin{array}{l}\text { Medicine, pharmacy and } \\
\text { nursing }\end{array}$ & $\begin{array}{l}\text { Theme-centred } \\
\text { workshops and } \\
\text { student seminars }\end{array}$ & $\begin{array}{l}\text { IPE seminars and workshops on medication } \\
\text { safety and therapeutics }\end{array}$ \\
\hline Heflin et al..$^{32} 2014$ & USA & Six professions & $\begin{array}{l}\text { Interactive lectures } \\
\text { in a common } \\
\text { setting }\end{array}$ & $\begin{array}{l}\text { Innovative prelicensure interprofessional } \\
\text { course designed to focus on improving } \\
\text { transitions of care for older adults through } \\
\text { interactive teaching sessions }\end{array}$ \\
\hline
\end{tabular}




\begin{tabular}{|c|c|c|c|}
\hline $\begin{array}{l}\text { Vanier et al. }{ }^{33} \\
2013\end{array}$ & Canada & $\begin{array}{l}\text { Students from } 10 \text { health } \\
\text { sciences and psychosocial } \\
\text { sciences training } \\
\text { programmes }\end{array}$ & $\begin{array}{l}\text { Patient-centred } \\
\text { case studies }\end{array}$ \\
\hline $\begin{array}{l}\text { Holland et al. } \\
2013\end{array}$ & UK & $\begin{array}{l}\text { Medicine, nursing and } \\
\text { physiotherapy }\end{array}$ & $\begin{array}{l}\text { Simulation- } \\
\text { based education } \\
\text { programme }\end{array}$ \\
\hline $\begin{array}{l}\text { Stebbins et al. }{ }^{35} \\
2013\end{array}$ & USA & $\begin{array}{c}\text { Pharmacy, medicine and } \\
\text { nursing }\end{array}$ & $\begin{array}{c}\text { Student-delivered } \\
\text { lectures }\end{array}$ \\
\hline $\begin{array}{l}\text { VanderWielen } \\
\text { et al. }{ }^{36} 2013\end{array}$ & USA & $\begin{array}{c}\text { Medicine, nursing, } \\
\text { dentistry, pharmacy, social } \\
\text { work, allied health and } \\
\text { dietetics }\end{array}$ & $\begin{array}{l}\text { Health promotion } \\
\text { activities }\end{array}$ \\
\hline $\begin{array}{l}\text { Fortugno et al. }{ }^{37} \\
2013\end{array}$ & Canada & $\begin{array}{l}\text { Nutrition, nursing, early } \\
\text { childhood education and } \\
\text { child and youth care }\end{array}$ & $\begin{array}{l}\text { Health promotion } \\
\text { activities }\end{array}$ \\
\hline Zhao et al..$^{38} 2013$ & USA & $\begin{array}{l}\text { Undergraduate health and } \\
\text { pre-health students }\end{array}$ & $\begin{array}{l}\text { Health promotion } \\
\text { activities }\end{array}$ \\
\hline $\begin{array}{l}\text { Smithburger } \\
\text { et al. }{ }^{39} 2013\end{array}$ & USA & $\begin{array}{c}\text { Medicine, pharmacy, } \\
\text { nursing, physician } \\
\text { assistants and social work }\end{array}$ & $\begin{array}{l}\text { Simulation- } \\
\text { based education } \\
\text { programme }\end{array}$ \\
\hline $\begin{array}{l}\text { MacDonell et al. }{ }^{40} \\
2012\end{array}$ & USA & $\begin{array}{l}\text { Medicine, nursing and } \\
\text { pharmacy }\end{array}$ & $\begin{array}{l}\text { Theme-centred } \\
\text { workshops }\end{array}$ \\
\hline Pinto et al..$^{41} 2012$ & Canada & $\begin{array}{l}\text { Dietetics, nuclear } \\
\text { medicine, nursing, } \\
\text { occupational therapy, } \\
\text { physical therapy, } \\
\text { pharmacy, radiation } \\
\text { therapy, radiological } \\
\text { technology, speech and } \\
\text { language pathology, social } \\
\text { work and therapeutic } \\
\text { recreation }\end{array}$ & $\begin{array}{l}\text { Patient-centred } \\
\text { case studies and } \\
\text { student seminars }\end{array}$ \\
\hline $\begin{array}{l}\text { Hasnain et al. }{ }^{42} \\
2012\end{array}$ & USA & Medicine and pharmacy & $\begin{array}{l}\text { Rotation in a } \\
\text { community setting }\end{array}$ \\
\hline $\begin{array}{l}\text { Leisnert et al. }{ }^{43} \\
2012\end{array}$ & Sweden & $\begin{array}{c}\text { Dental sciences and dental } \\
\text { hygiene }\end{array}$ & $\begin{array}{c}\text { Student-delivered } \\
\text { lectures and } \\
\text { student seminars }\end{array}$ \\
\hline
\end{tabular}
Patient representatives were involved in course planning and patients were trained to become patients-as-trainers and cofacilitate interprofessional discussion workshops
An IPE practice-based undergraduate module using acute simulation-based teaching
Trained pharmacy students delivered 60-90-minute standardised case-based lectures about drug cost-containment strategies to health professional students and prescribers

A student-led organisation provided health outreach events for underserved populations in the local community

Students collaborated to develop and deliver four healthy-living modules to secondary school students

Students formed an interprofessional and collaborative team for dissemination of nutrition/exercise knowledge

Complex clinical scenarios using simulation in small interprofessional teams

Workshop with an interdisciplinary team in a small-group setting

Introductory tutorial, patient-themed tutorials and an interprofessional student presentation

IMMERSe = Integrated Multidisciplinary Model of Education in Rural SEttings; FCM = family case management; IPC = interprofessional collaboration; $S W F S=$ senior wellness fairs; IPE = interprofessional education; $C H C=$ comprehensive healthcare; HIV = human immunodeficiency virus; $A I D S=$ acquired immune deficiency syndrome.

*Published online in January 2015 before print publication in 2016.

Simulation-based education programmes were a

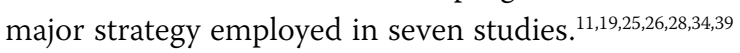
This important educational approach offers students the opportunity to apply learned theories and skills in a secure and monitored instructional atmosphere. This technique was imparted through virtual computer programmes, standardised patients, human/patient simulations during home health visits and simulation using manikins in clinical laboratories. In these studies, realistic patient-based scenarios were developed that could be managed only through interprofessional collaboration (IPC). ${ }^{11,19,25,26,28,34,39}$ Students were assigned to small interprofessional groups and assumed the role of their respective professions in simulated clinical environments.

Six studies pilot-tested the use of IPE modules in elective courses addressing the healthcare needs of underserved and general communities. . $17,20,24,29,42$ Not only did this strategy give students the opportunity to work collaboratively, but it also increased their confidence in caring for vulnerable populations and provided insight into the community's resources. In these studies, faculty from multiple disciplines collaborated with various community partners to develop and implement the elective course. Rural communities were found to be an ideal setting for students to experience interprofessional clinical practice and understand its importance. In some 
studies, the faculty and students constructed and conducted IPE activities which addressed the needs of underserved populations such as the elderly, those with human immunodeficiency/acquired immune deficiency syndrome and the homeless. ${ }^{6,20,24,29,36,42}$ These IPE activities were reported to result in longterm modifications in practices through the development of attitudes, values and competencies necessary to meet the health needs of vulnerable populations..$^{24}$ Another IPE strategy utilised was reallife clinical training in an interprofessional training ward in which senior healthcare students from a variety of disciplines worked in supervised teams to manage patients. ${ }^{27}$

Structured IPE consisting of patient-centred case studies for student discussion was also practiced in several institutions. ${ }^{33,41}$ Small groups were formed, including a representative from a real work setting so as to maximise potential gain for the students from these interactions. Debates on different approaches to patient care not only highlighted the importance of IPC but also enriched the learning experience. ${ }^{33,41}$ Theme-centred workshops conducted by students working in small interprofessional groups were also reported. ${ }^{26,28,30,31,40}$ These interactive teaching sessions promote critical thinking and effective communication as the students taught each other about various aspects of cases in small-group settings. Additional methods for imparting IPE included interprofessional student seminars, roleplaying and lectures from invited speakers. ${ }^{31,41,43}$

Lectures delivered by healthcare students to audiences composed of trainees from different disciplines were also utilised for IPE; these were reported to increase their confidence and awareness of future collaborative opportunities. ${ }^{21,35,43}$ Students also formed interprofessional and collaborative teams in order to take part in community health promotion activities. ${ }^{22,36-38}$ Combined interactive lectures for students from various health professions also provided opportunities for student interaction and reflection. ${ }^{23,32}$

\section{Discussion}

The provision of IPE activities during training is crucial to the development of an efficient and effective workforce. It is considered to be an important approach for improving the quality of overall patient care as it encourages interprofessional team-based collaboration among future healthcare professionals. ${ }^{5,44}$ Within a healthcare setting, IPE is recognised as a means of challenging the usual intraprofessional training in order to find new responses to healthcare issues, which include the increasing complexity of care needs and the fragmentation of care provided by different specialties. ${ }^{45}$ In this literature review, nine main strategies were identified for executing IPE activities. ${ }^{6,11,17,19-43}$ These diverse educational approaches, when implemented in combination, have the potential to provide a strong base for the interprofessional training of undergraduate healthcare professionals.

\section{LEVELS OF INTERACTION}

IPE activities provide an opportunity to train healthcare students in a safe environment through observation, hands-on training, team interaction and critical feedback. ${ }^{27}$ It is also apparent that IPE modifies the attitudes of prospective healthcare professionals by exposing them to three levels of interactioncommunication, mutual respect/trust and teamwork, thus facilitating the adoption of IPC in healthcare settings. ${ }^{46}$

\section{Communication}

IPE provides opportunities to develop and demonstrate the verbal and nonverbal communication skills necessary for appropriate, confident and effective interactions with colleagues and patients and their relatives or carers..$^{25}$

\section{Mutual respect and trust}

For the learner, participation in IPE activities clarifies their responsibilities while still continuing their education. ${ }^{47}$ This approach provides the opportunity for individuals in healthcare disciplines to share their skills and knowledge, thus fostering shared values and a better understanding of their own roles and abilities. IPE increases student awareness of the roles, functions, expertise and services provided by other healthcare professionals. ${ }^{48}$ Thus, IPE builds mutual trust and respect between different healthcare specialties, provides students with a better understanding of the roles and limitations of various professions and facilitates team-building. A key strength of IPE is building interprofessional trust between healthcare workers who will work together in the future. ${ }^{20,30,36}$

\section{Teamwork}

IPE is reported as a means to enhance flexibility and adaptability, which are important for team-building and maintaining positive working relationships. ${ }^{17}$ Students get the opportunity to undertake various roles-including both leader and follower-and contribute effectively as part of a multidisciplinary team, thus producing a practice-ready graduate possessing the appropriate teamwork skills. ${ }^{47}$ The ultimate aim in all IPE activities is to learn with and from members of other professions so as to improve both professional attitudes and patient care delivery. 
Therefore, IPE is regarded as a crucial step in training collaborative practice-ready personnel. ${ }^{2}$ IPE activities have been reported to enhance students' thinking and communication regarding collaborative practice, which will eventually improve patient care. ${ }^{24}$

\section{IMPLEMENTATION IN THE CURRICULUM}

Key concepts for the implementation of IPE in medical undergraduate curriculum include early introduction, utilisation of a variety of settings and scenarios, a variety of different instructional methods and incorporation of IPE into existing courses instead of as an additional separate course. ${ }^{26}$ With this in mind, the authors suggest a longitudinal curriculum design including a variety of interprofessional events embedded in practical learning experiences which provide exposure to simple and more complex collaboration activities over time. An IPE curriculum must advocate delivering high-quality patient care using active learning strategies. ${ }^{11}$ Stand-alone schools are advised to collaborate with local health institutions and neighbouring universities in conjunction with additional allied health programmes in order to incorporate students from multiple disciplines into their IPE curriculum. ${ }^{25}$

Another vital fact to consider while designing IPE activities is that they should be structured with specific learning outcomes in which the interactions between healthcare profession students are purposefully organised and facilitated. ${ }^{41}$ For students, reviewing available literature and online resources prior to the IPE session should be encouraged as it could facilitate preparation for what might be expected of them during the session. ${ }^{25}$ Facilitated team-based learning sessions and reflection of the students' experiences could also help in identifying profession-related and generic responsibilities, thus assisting students' learning experiences. $^{49}$ Other recommendations include the importance of training students to investigate failures in group dynamics through a team-based approach, ensuring reflection of perceived team interactions and designing probing sessions around concepts of successful interprofessional teamwork to direct students towards enhanced understanding of the complexities of collaborative care. ${ }^{47}$

\section{Assessing impact}

The impact of various IPE activities on competencies and perceptions/opinions regarding IPC have been assessed in many studies by administering a survey instrument before and after the course and/or an interprofessional objective-structured clinical examination. ${ }^{12,26}$ However, as standardised methods for the assessment of interprofessional competencies are not well established, research and the development of instruments to assess meaningful outcomes of IPE should be encouraged. ${ }^{41}$ Subsequent to each IPE experience, the students should also receive formative feedback and reflect on IPC. During the course of the curriculum, multiple experiences of the cyclical process of IPE exercises followed by feedback and reflection would improve and strengthen IPE concepts. ${ }^{26}$ Regular feedback could also be used to improve IPE activities. ${ }^{17}$

Several studies have revealed that students who participate in IPE experiences demonstrate positive changes in their opinions regarding the advantages of IPC and have enhanced professional self-confidence and a stronger sense of clinical competence. ${ }^{35,42}$ These positive changes have also been identified as being responsible for improved team dynamics and hindering the development of negative stereotypes in health professionals. ${ }^{41}$

\section{Challenges to implementation}

Despite formal recommendations supporting IPE, the successful design and implementation of IPE programmes in health profession curricula is limited. The various intricacies involved in conducting IPE exercises may be one of the main reasons for the minimal incorporation of IPE in health professional education at many universities. ${ }^{6}$ There is also a need for agreement about crucial learning outcomes for IPE worldwide. More models of best practice are required, as reliable methods to design and deliver IPE in a curriculum do not exist. ${ }^{26,27}$ A lack of standardised assessment instruments are also a barrier as they are needed to facilitate the implementation of IPE. ${ }^{12}$

Health profession schools have encountered several difficulties while implementing IPE, such as a lack of facilities, trained personnel, adequate clinical training sites and the necessary IPE resources, as well as space constraints and limited access to other healthcare disciplines. ${ }^{47}$ Additionally, institutions can face difficulties in scheduling as students of different professions must be taught in the same setting in order to learn together. ${ }^{47}$ Vanderwielen et al. also noted resistance to IPE among faculty members due to the increased workload and a lack of time for the development and implementation of IPE activities within the curriculum. ${ }^{47}$ As any successful curricular innovation requires support from all stakeholders, education and training of the IPE facilitators through faculty development programmes will improve the quality of IPE sessions, in addition to reinforcing collective ownership of IPE activities. ${ }^{26}$ In addition, the support of senior management is essential for 
the smooth and widespread incorporation of such activities in health profession education. ${ }^{50}$

Analysis of the studies in this review gave inconclusive evidence on the effectiveness of IPE on outcomes, mainly due to the difficulty in measuring these reliably. ${ }^{6}$ Most studies only analysed immediate changes in attitudes, knowledge and skills following the intervention and did not provide long-term data on which to base assessments of the efficacy of the interventions and their transferability to clinical practice. $^{40}$ Furthermore, the existing literature on IPE was found to be inadequate, with poorly defined outcome validity and/or reliability measures and many studies lacking a control group. This indicates the need for the development and implementation of standard IPE programmes, along with high-quality research to assess the long-term effects of IPE activities. ${ }^{41}$ Although IPE initiatives can improve the quality of healthcare personnel, maximum benefits can only be attained with the simultaneous development of interprofessional culture in healthcare settings. However, this appears to be a challenging task as it requires multiple levels of collaborative effort from health professionals and healthcare organisations. ${ }^{50}$ The current review has a few limitations. Although the data abstraction form was developed and refined, external experts were not consulted. Furthermore, another limitation was the lack of strict quality assessment for the included articles.

\section{Conclusion}

This descriptive qualitative literature review focused on IPE issues involving undergraduate healthcare students and the current approaches and models used to impart IPE worldwide. Nine main strategies were identified for executing IPE activities. The benefits of including IPE within the undergraduate health profession curriculum include enhanced knowledge about the benefits of collaboration, appreciation of the roles of other health professionals and improvement in individual competencies. However, there is an on-going need to evaluate the effectiveness of IPE activities on learning outcomes. Although many challenges exist, recommendations synthesised from diverse approaches are expected to assist in developing sustainable strategies for implementing IPE longitudinally in various healthcare curricula.

\section{ACKNOWLEDGEMENTS}

The Gulf Medical University, Ajman, United Arab Emirates, provided a research assistant for data collection.

\section{References}

1. Reeves S, Zwarenstein M, Goldman J, Barr H, Freeth D, Hammick $\mathrm{M}$, et al. Interprofessional education: Effects on professional practice and health care outcomes. Cochrane Database Syst Rev 2008; 1:CD002213. doi: 10.1002/14651858.CD002213.pub2.

2. World Health Organization. Health workforce: Framework for action on interprofessional education and collaborative practice. From: www.who.int/hrh/resources/framework_action /en/index.html Accessed: May 2016.

3. Committee on Quality of Healthcare in America, Institute of Medicine. Crossing the Quality Chasm: A new health system for the 21st century, 1st ed. Washington DC, USA: National Academies Press, 2001.

4. Barr H, Koppel I, Reeves S, Hammick M, Freeth DS. Effective Interprofessional Education: Argument, assumption and evidence, 1st ed. Oxford, UK: Wiley-Blackwell, 2005. doi: 10.1002/9780470776445.

5. Interprofessional Education Collaborative. Core competencies for interprofessional collaborative practice: Report of an expert panel, May 2011. From: www.aacn.nche.edu/educationresources/ipecreport.pdf Accessed: May 2016.

6. Gum LF, Richards JN, Walters L, Forgan J, Lopriore M, Nobes C. Immersing undergraduates into an interprofessional longitudinal rural placement. Rural Remote Health 2013; 13:2271.

7. Sargeant J, Loney E, Murphy G. Effective interprofessional teams: "Contact is not enough" to build a team. J Contin Educ Health Prof 2008; 28:228-34. doi: 10.1002/chp.189.

8. Zwarenstein $\mathrm{M}$, Goldman J, Reeves S. Interprofessional collaboration: Effects of practice-based interventions on professional practice and healthcare outcomes. Cochrane Database Syst Rev 2009; 3:CD000072. doi: 10.1002/14651858. CD000072.pub2.

9. World Health Organization. Learning together to work together for health: Report of a WHO study group on multiprofessional education for health personnel - The team approach. World Health Organ Tech Rep Ser 1988; 769:1-72.

10. Centre for the Advancement of Interprofessional Education. Principles of interprofessional education. From: www.caipe. org.uk/resources/principles-of-interprofessional-education/ Accessed: May 2016.

11. Vyas D, McCulloh R, Dyer C, Gregory G, Higbee D. An interprofessional course using human patient simulation to teach patient safety and teamwork skills. Am J Pharm Educ 2012; 76:71. doi: 10.5688/ajpe76471.

12. Jones KM, Blumenthal DK, Burke JM, Condren M, Hansen R, Holiday-Goodman $\mathrm{M}$, et al. Interprofessional education in introductory pharmacy practice experiences at US colleges and schools of pharmacy. Am J Pharm Educ 2012; 76:80. doi: 10.5688 /ajpe76580.

13. Yan J, Gilbert JH, Hoffman SJ. World Health Organization study group on interprofessional education and collaborative practice. J Interprof Care 2007; 21:588-9. doi: 10.1080/ 13561820701775830 .

14. Garling P. Final report of the special commission of inquiry: Acute care services in NSW public hospitals - Overview. From: www. dpc.nsw.gov.au/_data/assets/pdf_file/0003/34194/Overview_Special_Commission_Of_Inquiry_Into_Acute_Care_Services_ In_New_South_Wales_Public_Hospitals.pdf Accessed: May 2016.

15. Mann KV, Mcfetridge-Durdle J, Martin-Misener R, Clovis J, Rowe $\mathrm{R}$, Beanlands $\mathrm{H}$, et al. Interprofessional education for students of the health professions: The "Seamless Care" model. J Interprof Care 2009; 23:224-33. doi: 10.1080/135 61820802697735 .

16. Iroku-Malize T, Matson C, Freeman J, McGrew M, David A; ADFM Education Transformation Committee. Interprofessional education. Ann Fam Med 2013; 11:188-9. doi: 10.1370/afm.1523. 
17. Opina-Tan LA. A pilot implementation of interprofessional education in a community-academe partnership in the Philippines. Educ Health (Abingdon) 2013; 26:164-71. doi: 10.41 03/1357-6283.125992.

18. Inuwa IM. Interprofessional education (IPE) activity amongst health sciences students at Sultan Qaboos University: The time is now! Sultan Qaboos Univ Med J 2012; 12:435-41. doi: 10.12 $816 / 0003168$.

19. Wang R, Shi N, Bai J, Zheng Y, Zhao Y. Implementation and evaluation of an interprofessional simulation-based education program for undergraduate nursing students in operating room nursing education: A randomized controlled trial. BMC Med Educ 2015; 15:115. doi: 10.1186/s12909-015-0400-8.

20. Cappiello JD, Joy J, Smith P, Orgren RA. The SEARCH Project: Acquainting students in the health professions with interprofessional care. J Allied Health 2015; 44:91-5.

21. McBride JM, Drake RL. Student perceptions of an interprofessional educational experience: The importance of goal articulation. Anat Sci Educ 2015; 8:381-5. doi: 10.1002/ase.1547.

22. Diwan S, Perdue M, Lee SE, Grossman BR. Health promotion practice and interprofessional education in aging: Senior wellness fairs. Gerontol Geriatr Educ 2016; 37:145-66. doi: 10.1080/02701960.2015.1005290.

23. Herrmann G, Woermann U, Schlegel C. Interprofessional education in anatomy: Learning together in medical and nursing training. Anat Sci Educ 2015; 8:324-30. doi: 10.1002/ase.1506.

24. Arndell C, Proffitt B, Disco M, Clithero A. Street outreach and shelter care elective for senior health professional students: An interprofessional educational model for addressing the needs of vulnerable populations. Educ Health (Abingdon) 2014; 27:99-102. doi: 10.4103/1357-6283.134361.

25. Bolesta S, Chmil JV. Interprofessional education among student health professionals using human patient simulation. Am J Pharm Educ 2014; 78:94. doi: 10.5688/ajpe78594.

26. Shrader S, Griggs C. Multiple interprofessional education activities delivered longitudinally within a required clinical assessment course. Am J Pharm Educ 2014; 78:14. doi: 10.5688/ ajpe78114.

27. Morphet J, Hood K, Cant R, Baulch J, Gilbee A, Sandry K. Teaching teamwork: An evaluation of an interprofessional training ward placement for health care students. Adv Med Educ Pract 2014; 5:197-204. doi: 10.2147/AMEP.S61189.

28. von der Lancken S, Levenhagen K. Interprofessional teaching project with nursing and physical therapy students to promote caregiver and patient safety. J Nurs Educ 2014; 53:704-9. doi: 10.3928/01484834-20141118-14

29. Tan CE, Jaffar A, Tong SF, Hamzah MS, Mohamad N Comprehensive healthcare module: Medical and pharmacy students' shared learning experiences. Med Educ Online 2014; 19:25605. doi: 10.3402/meo.v19.25605

30. Netherwood $M$, Derham R. Interprofessional education: Merging nursing, midwifery and CAM. Br J Nurs 2014; 23:740-3. doi: 10.12968/bjon.2014.23.13.740.

31. Hardisty J, Scott L, Chandler S, Pearson P, Powell S. Interprofessional learning for medication safety. Clin Teach 2014; 11:290-6. doi: 10.1111/tct.12148.

32. Heflin MT, Pinheiro SO, Konrad TR, Egerton EO, Thornlow DK, White HK, et al. Design and evaluation of a prelicensure interprofessional course on improving care transitions. Gerontol Geriatr Educ 2014; 35:41-63. doi: 10.10 80/02701960.2013.831349.

33. Vanier MC, Therriault PY, Lebel P, Nolin F, Lefebvre H, Brault I, et al. Innovating in teaching collaborative practice with a large student cohort at Université de Montréal. J Allied Health 2013; 42:e97-106.

34. Holland C, Bench S, Brown K, Bradley C, Johnson L, Frisby J. Interprofessional working in acute care. Clin Teach 2013; 10:107-12. doi: 10.1111/tct.12002.
35. Stebbins MR, Frear ME, Cutler TW, Lightwood JM, Fingado AR, Lai CJ, et al. Pharmacy students teaching prescribers strategies to lower prescription drug costs for underserved patients. J Manag Care Pharm 2013; 19:534-41. doi: 10.18553/jmcp.2013.19.7.534.

36. VanderWielen LM, Enurah AS, Osburn IF, LaCoe KN, Vanderbilt AA. The development of student-led interprofessional education and collaboration. J Interprof Care 2013; 27:422-3. doi: $10.3109 / 13561820.2013 .790882$.

37. Fortugno M, Chandra S, Espin S, Gucciardi E. Fostering successful interprofessional teamwork through an undergraduate student placement in a secondary school. J Interprof Care 2013; 27:326-32. doi: 10.3109/13561820.2012.759912.

38. Zhao SR, Cao S, Lin PS, Yenor J, Lam R, Chang E, et al. Interprofessional and interdisciplinary approach from undergraduate health and pre-medical students in children's health educational initiative. J Community Med Health Educ 2013; 4:1000266. doi: 10.4172/2161-0711.1000266.

39. Smithburger PL, Kane-Gill SL, Kloet MA, Lohr B, Seybert AL. Advancing interprofessional education through the use of high fidelity human patient simulators. Pharm Pract (Granada) 2013; 11:61-5

40. MacDonnell CP, Rege SV, Misto K, Dollase R, George P. An introductory interprofessional exercise for healthcare students. Am J Pharm Educ 2012; 76:154. doi: 10.5688/ajpe768154.

41. Pinto A, Lee S, Lombardo S, Salama M, Ellis S, Kay T, et al. The impact of structured inter-professional education on health care professional students' perceptions of collaboration in a clinical setting. Physiother Can 2012; 64:145-56. doi: 10.3138/ptc.2010-52.

42. Hasnain M, Koronkowski MJ, Kondratowicz DM, Goliak KL. Training future health providers to care for the underserved: A pilot interprofessional experience. Educ Health (Abingdon) 2012; 25:204-7. doi: 10.4103/1357-6283.109790.

43. Leisnert L, Karlsson M, Franklin I, Lindh L, Wretlind K. Improving teamwork between students from two professional programmes in dental education. Eur J Dental Educ 2012; 16:17-26. doi: 10.1111/j.1600-0579.2011.00702.x.

44. Oandasan I, Reeves S. Key elements of interprofessional education: Part 2 - Factors, processes and outcomes. J Interprof Care 2005; 19:39-48. doi: 10.1080/13561820500081703.

45. Peduzzi M, Norman IJ, Germani AC, da Silva JA, De Souza GC. [Interprofessional education: Training for healthcare professionals for teamwork focusing on users]. Rev Esc Enfem USP 2013; 47:977-83. doi: 10.1590/S0080-623420130000400029.

46. Guitard P, Dubouloz CJ, Savard J, Metthé L, Brasset-Latulippe A. Assessing interprofessional learning during a student placement in an interprofessional rehabilitation university clinic in primary healthcare in a Canadian francophone minority context. J Res Interprof Pract Educ 2010; 1:231-46.

47. Vanderwielen LM, Vanderbilt AA, Dumke EK, Do EK, Isringhausen $\mathrm{KT}$, Wright MS, et al. Improving public health through student-led interprofessional extracurricular education and collaboration: A conceptual framework. J Multidiscip Healthc 2014; 7:105-10. doi: 10.2147/JMDH.S52019.

48. Klasser GD, Gremillion HA. Past, present, and future of predoctoral dental education in orofacial pain and TMDs: A call for interprofessional education. J Dent Educ 2013; 77:395-400.

49. Gilligan C, Outram S, Levett-Jones T. Recommendations from recent graduates in medicine, nursing and pharmacy on improving interprofessional education in university programs: A qualitative study. BMC Med Educ 2014; 14:52. doi: 10.1186/14726920-14-52.

50. Oeseburg B, Hilberts R, Luten TA, van Etten AV, Slaets JP, Roodbol PF. Interprofessional education in primary care for the elderly: A pilot study. BMC Med Educ 2013; 13:161. doi: 10.1186/1472-6920-13-161. 